\title{
NoTe
}

\section{Locke v. Davey: Discretion, Discrimination, and the New Free Exercise ${ }^{*}$}

\section{INTRODUCTION}

The First Amendment to the United States Constitution reads, in pertinent part, "Congress shall make no law respecting the establishment of religion, or prohibiting the free exercise thereof." The Supreme Court and many commentators have long subscribed to the notion that this language cannot be read as a whole but that the two clauses must be read independently. ${ }^{2}$ The crux of much Religion Clause jurisprudence lies in the inherent tension in giving full legal effect to each clause. As Chief Justice Burger wrote in Walz v. Tax Commission, "[ $t$ ]he Court has struggled to find a neutral course between the two religion clauses, both of which are cast in absolute terms, and either of which, if expanded to a logical extreme, would tend to clash with the other." 3 Problems frequently arise in situations where a neutral, generally applicable law affects religious exercise. On the one hand, a failure to make exceptions to such laws for religious practices may end up burdening free exercise. On the other, granting such exceptions arguably constitutes a governmental establishment of religion, in the sense that the government is advancing, or at least aiding, that religion. Such issues have vexed the Court for years in diverse situations, ranging from whether to grant churches tax exemptions, ${ }^{4}$ to whether to allow exceptions to truancy laws for children attending religious education classes. ${ }^{5}$ In recent years, the

\footnotetext{
* Matthew Gaus. The author thanks Professor Richard Levy for his invaluable guidance and commentary throughout the writing of this Note.

1. U.S. CONST. amend. I. The Religion Clauses were first incorporated into the Fourteenth Amendment and applied to the states by Cantwell v. Connecticut, 310 U.S. 296 (1940).

2. See, e.g., Tilton v. Richardson, 403 U.S. 672, 677 (1971) ("Numerous cases considered by the Court have noted the internal tension in the First Amendment between the Establishment Clause and the Free Exercise Clause.").

3. 397 U.S. $664,668-69$ (1970).

4. Id.

5. Zorach v. Clauson, 343 U.S. 306 (1952).
} 
tension between the clauses often has been at issue in cases involving the availability of public funding for religious education.

The Supreme Court's recent decision in Locke v. Davey ${ }^{6}$ exemplifies the two clauses in conflict. At issue in Locke was a program established by the Washington State Legislature awarding scholarship funding to all qualifying, Washington high-school seniors. The legislation establishing the program expressly excluded those students studying devotional theology. This program was challenged as violating the free exercise rights of potential devotional theology majors. A strong argument could be made that it did. A similarly strong argument could be made that the exception helped protect the establishment concerns held by Washington lawmakers and citizens.

A decision holding the exception to be a violation of free exercise rights would have been in line with the Court's recent trend toward an accommodation of religious institutions in receiving public educational funding. This trend culminated in 2002's Zelman v. Simmons-Harris, ${ }^{7}$ which held constitutional an Ohio program allowing parents to use publicly funded educational vouchers to send their children to parochial schools. Additionally, such a decision could have found justification in the "neutrality principle" the Court has begun to articulate during the last fifteen years: the notion that a law may burden free exercise only if it is facially neutral in regard to religion. ${ }^{8}$ The Washington scholarship exception may arguably be seen as facially discriminatory.

The Locke Court, however, in a seven-to-two decision, held that the Washington theology exception did not impermissibly burden free exercise rights. ${ }^{9}$ This is a notable decision in several respects. First, the primary dispute between the majority and the dissent reveals a fundamental clash in Religion Clause priorities within the Court. One side favors continuing the general trend of accommodation of religion into public funding schemes, while the other gives priority to the more recent trend of increasing deference to state and local governments in resolving church-state controversies. The Court in recent years has

6. 540 U.S. 712 (2004).

7. 536 U.S. 639 (2002).

8. See Church of the Lukumi Babalu Aye, Inc. v. City of Haileah, 508 U.S. 520, 546 (1993) (holding that statutes burdening free exercise that are not facially neutral are to be subjected to strict scrutiny); Employment Div., Dep't of Human Res. v. Smith, 494 U.S. 872, 878 (1990) (holding that a neutral law of general applicability need not be justified by a compelling state interest); see also infra Part II.D.

9. Locke, 540 U.S. at 715. 
shown a willingness to defer to state and local authorities so long as minimum requirements of neutrality and general applicability are met. ${ }^{10}$

Both the trend of deferring to local governments and the trend of accommodating religious groups could comfortably coexist in a case such as Zelman, where approving a neutral, generally applicable educational program necessarily coincided with giving the state government the power to regulate its own affairs. ${ }^{11}$ In Locke, the two trends could not coexist as neatly. The result in Locke can be explained by a majority of the Court giving priority to local and state political processes in resolving disputes, rather than adhering to the ideal of neutrality or the desire to accommodate religious groups.

Second, taken together with Zelman, Locke now allows states to decide whether religious institutions may participate in state educational funding programs. In other words, Locke finishes creating a zone of state and local discretion, a gray area between the religion clauses in which it indicates the Supreme Court will not interfere. ${ }^{12}$ Though the Locke Court ostensibly limits its holding to the facts of the case, this zone of discretion is easily applied to any matter in which the federal government imposes on state and local governments any obligations or restrictions which concern a religious issue.

This Note argues that the Locke decision is, at the least, doctrinally sound. It logically places the case in the same line as other denial-ofbenefit cases, helps to clarify the strictness of the neutrality principle, and provides a complement to the Court's Establishment Clause doctrine. Further, it does not seem likely to increase the potential for religious discrimination, as the dissent fears. However, because of the decision's weaknesses - a failure to clearly delineate precisely how far a state may stray from strict neutrality and a failure to state its theoretical position as precisely as the dissent does - the post-Zelman tide of litigation seeking to force equal government funding for parochial education is not completely stemmed. Perhaps more importantly, the Court seems to have opened up the floor for more state, rather than federal, litigation in the religious arena without precisely setting out the ground rules.

This Note begins with an examination of various facets of Religion Clause jurisprudence, particularly focusing on how the court historically has dealt with the tension between the Establishment Clause and the Free Exercise Clause. After a detailed discussion of the case itself, the Note

10. See infra Parts II, III.A.

11. See generally 536 U.S. 639.

12. For a more detailed discussion of this zone of discretion, see infra Part III.A. 
will argue that Locke, in tandem with Zelman, has the effect of delegating to state legislatures some of the review authority the Court once reserved for itself. It will explore why the Court seems to be shifting away from the emphasis on neutrality underlying recent Religion Clause decisions toward a more flexible, decentralized approach; discuss the possible ramifications of this shift; and examine post-Locke litigation to determine what the decision portends for the immediate future of Religion Clause jurisprudence.

\section{BACKGROUND}

\section{A. Everson: Strict Separation and a Single Reading of the Religion Clauses}

The development of Supreme Court jurisprudence regarding the required level of state neutrality toward religion reflects the gradual recognition that the two clauses should be considered independently, notwithstanding the resulting tension between the absolute language of the clauses. This separate consideration has not always been the case. Modern Establishment Clause jurisprudence has its genesis in 1947's landmark decision, Everson v. Board of Education. ${ }^{13}$ Everson held constitutional a New Jersey statute authorizing local school boards to reimburse parents of parochial school students for public transportation expenses. ${ }^{14}$

The Everson majority characterized the two religion clauses as "interrelated" and "complementary," and it expressed little trouble in reconciling the two: "[ $t]$ he structure of our government has, for the preservation of civil liberty, rescued the temporal institutions from religious interference. On the other hand, it has secured religious liberty from the invasion of the civil authority." "15 The inherent tension between the clauses might have gone unrecognized because the New Jersey program implicated the Establishment Clause to a greater extent than it did the Free Exercise Clause. A better explanation might be that the strict-separation doctrine espoused by the Everson Court did not require a reading of the clauses as separate entities. ${ }^{16}$ Basing the

13. 330 U.S. 1 (1947).

14. Id. at 3 .

15. Id. at 15 (quoting Watson v. Jones, 80 U.S. (13 Wall.) 679, 730 (1871)).

16. See generally Marsh v. Chambers, 463 U.S. 783, 821-22 (1983) (Brennan, J., dissenting) (implying that religious liberty is best guaranteed by Establishment Clause prohibitions); see also 
discussion largely on the writings of Madison and Jefferson, the Court found that the Framers generally intended "a strict wall of separation" between church and state. ${ }^{17}$ Specifically, all nine Justices agreed with the majority's language:

Neither a state nor the Federal government ... can pass laws which aid one religion, aid all religions, or prefer one religion over another .... No tax in any amount, large or small, can be levied to support any religious activities or institutions, whatever they may be called, or whatever form they may adopt to teach or practice religion. ${ }^{18}$

It is doubtful, however, that a majority of the Court has ever truly followed the strict-separation doctrine. After its strong declaration of principle, the majority in Everson upheld the New Jersey program, analogizing the program to public services traditionally provided to religious and non-religious institutions alike - police or fire protection, for example. ${ }^{19}$ Though not specifically stated, the impossibility of true separation was made evident by the contradictory decision. ${ }^{20}$

\section{B. Accepting Tension and the Rise of Accommodation}

The Religion Clause decisions that followed in the next several decades began to explore a more realistic framework with which to evaluate government neutrality toward religion. The majority wrote in 1952's Zorach v. Clauson ${ }^{21}$ that the First Amendment "does not say that in every and all respects there shall be a separation of Church and State."22 The Court again noted that such a position would render religious institutions incapable of receiving basic public services. ${ }^{23}$ It further warned against allowing church-state relations to become "hostile, suspicious, and even unfriendly." Similarly, 1968's Board of

\footnotetext{
Sch. Dist. v. Schempp, 374 U.S. 203, 232-33 (1963) (stating that protection of religious freedoms does not rest solely on either clause).

17. Everson, 330 U.S. at 16.

18. Id. at $15-16$.

19. Id. at 17 .

20. See Joseph P. Viteritti, Davey's Plea: Blaine, Blair, Witters, and the Protection of Religious Freedom, 27 HARV. J.L. \& PUB. POL'Y 299, 326 (2003) (discussing the "jumble of mixed messages" set forth in Everson).

21. 343 U.S. 306 (1952).

22. Id. at 312. Zorach upheld a state program allowing schoolchildren to be released early to attend outside religious education classes.

23. Id.

24. Id.
} 
Education v. Allen ${ }^{25}$ explicitly recognized that "religious schools pursue two goals, religious instruction and secular education." "26 The Allen court refused to endorse the notion that the two goals were "so intertwined that secular textbooks furnished to students by the public are in fact instrumental in the teaching of religion." ${ }^{27}$ This was the first real signal that the Court was willing to show any accommodation of parochial schools in public funding schemes.

Two years later, in Walz v. Tax Commission, ${ }^{28}$ the Court for the first time explicitly acknowledged that the difficulty in determining the proper level of governmental neutrality stemmed from the difficulty in reconciling the absolute language of the two clauses. ${ }^{29}$ The Court wrote that " $[\mathrm{t}]$ he considerable internal inconsistency in the [Religion Clause] opinions of the Court derives from what ... may have been too sweeping utterances on aspects of these clauses that seemed clear in relation to the particular cases but have limited meaning in general principle." ${ }^{30}$ The Court recognized that a rigid interpretation of the language could subvert the purposes of the religion clauses: "to insure that no religion be sponsored or favored, none commanded, and none inhibited." 31 In holding constitutional a program of tax exemptions for religious institutions, the Court wrote,

we will not tolerate either governmentally established religion or governmental interference with religion. Short of those expressly proscribed governmental acts there is room for play in the joints productive of a benevolent neutrality which will permit religious exercise to exist without sponsorship and without interference. ${ }^{32}$

While this concept of "play in the joints" was not heavily drawn upon (at least explicitly) in later jurisprudence, ${ }^{33}$ both the idea of "benevolent neutrality" and the concept of inherent tension between the clauses featured prominently in later decisions.

25. 392 U.S. 236 (1968).

26. Id. at 245. Allen upheld a New York program in which parochial schools were lent textbooks by public schools.

27. Id. at 248

28. 397 U.S. 664 (1970).

29. Id. at $668-69$.

30. Id. at 668 .

31. Id. at 669 .

32. Id.

33. Between 1971 (Walz) and 2004 (Locke) the Supreme Court cited the concept of "play in the joints" in the Religion Clause context only four times. Bd. of Ed. v. Grumet, 512 U.S. 687 (1994); County of Allegheny v. ACLU, 492 U.S. 573 (1989); Sloan v. Lemon, 413 U.S. 825 (1973); Norwood v. Harrison, 413 U.S. 455 (1973). 


\section{Establishment and Accommodation: From Lemon to Zelman}

The idea that the state should act with benevolent neutrality toward religion gave rise to a growing willingness to accommodate religious institutions in general public programs. The rise and fall of the neutrality test first set forth in 1971's Lemon v. Kurtzman ${ }^{34}$ demonstrates this growing accommodationist trend. Lemon reiterated that "total separation [of church and state] is not possible in an absolute sense." ${ }^{35}$ Lemon proposed a three-prong test to use in evaluating whether a statute violated the Establishment Clause: "First, the statute must have a secular legislative purpose; second, its principal or primary effect must be one that neither advances nor inhibits religion; finally, the statute must not foster 'an excessive government entanglement with religion.",36

In its initial appearance, the test was rigidly applied. Lemon held unconstitutional two state statutes that granted some state funds to supplement the salaries of parochial school teachers of secular subjects. The majority found that "the very restrictions and surveillance necessary to ensure that teachers play a strictly non-ideological role give rise to entanglements between church and state." ${ }^{, 37}$ For the next decade the Court's focus in this area shifted to the potential divertibility of public funds. That is, the Court primarily upheld programs where little monitoring was required to ensure that state funds would not be used for religious purposes, and it struck down programs where substantial monitoring was required. ${ }^{38}$

The inherent flexibility in interpreting the prongs of the Lemon test, however, opened up opportunities for a majority with a more accommodationist view of religion. In 1983's Mueller v. Allen, the Court upheld a program allowing parents of parochial school children to

\footnotetext{
34. 403 U.S. 602 (1971).

35. Id. at 614 .

36. Id. at 612-13 (quoting Walz, 397 U.S. at 674)). The first two prongs of the Lemon test were drawn from School District v. Schempp, 374 U.S. 203, 222 (1963).

37. Id. at 620-21.

38. See, e.g., Roemer v. Bd. of Pub. Works, 426 U.S. 736 (1976) (holding constitutional a state grant program to private and religious universities, where a strict program was in place); Levitt $\mathrm{v}$. Comm. for Public Educ. \& Religious Liberty, 413 U.S. 472 (1973) (holding unconstitutional reimbursement to religious schools for mandatory school testing); Tilton v. Richardson, 403 U.S. 672 (1971) (holding constitutional federal building grants to church-run colleges and universities); see also Zelman v. Simmons-Harris, 536 U.S. 639, 691-92 (2002) (Souter, J., dissenting) ("To avoid ... entanglement, the Court's focus in the post-[Board of Education v.] Allen cases was on the principle of divertibility.").
} 
take a tax deduction for tuition and expenses. ${ }^{39}$ The factual situation in Mueller was nearly identical to Committee for Public Education \& Religious Liberty v. Nyquist ${ }^{40}$ decided a decade earlier. In Nyquist, the Court held that such a program violated the "principal or primary effect" prong of the Lemon test. ${ }^{41}$ This was because of "the absence of an effective means of guaranteeing that the state aid derived from public funds will be used exclusively for secular, neutral, and nonideological purposes." program, placing special emphasis on the fact that the tax deduction was one of many offered to Minnesota citizens for a variety of purposes, including medical expenses and charitable contributions. ${ }^{43}$ The Court also relied on the fact that the Mueller program, unlike the Nyquist program, was available to parents of all schoolchildren, not just those attending non-public schools. ${ }^{44}$

While important as a signal that the Court found Lemon a less-thanuseful tool in determining Establishment Clause violations, Mueller more importantly marked a turning point for the Court's treatment of establishment issues. The cases that followed in the next few decades began increasingly to allow for state aid to religious schools by emphasizing "neutral availability for religious and secular educational expenses and the role of private choice." 45 Witters $v$. Washington Department of Services for the Blind ${ }^{46}$ exemplifies this line of cases. Witters approved a blind student's use of a state-funded vocational training subsidy to be used at a religious college. ${ }^{47}$ The Witters Court emphasized that "[a]ny aid provided under Washington's program that ultimately flows to religious institutions does so only as the result of the

\footnotetext{
39. 463 U.S. 388 (1983).

40. 413 U.S. 756 (1973).

41. Id.

42. Id. at 780 .

43. Mueller, 463 U.S. at 396.

44. Id. at 397 .

45. Zelman v. Simmons-Harris, 536 U.S. 639, 694 (2002) (Souter, J., dissenting). See, e.g., Agostini v. Felton, 521 U.S. 203 (1997) (holding that a state program paying remedial teachers of secular subjects to teach in parochial schools was constitutional and finding it sufficient that public aid to parochial schools supplemented but did not supplant existing educational services); Rosenberger v. Rector and Visitors of the Univ. of Va., 515 U.S. 819 (1995) (holding unconstitutional a ban on allowing student religious organizations access to a general student activity fund and emphasizing the neutrality of the program and the role of individual choice); Zobrest v. Catalina Foothills Sch. Dist., 509 U.S. 1 (1993) (upholding a deaf parochial student's use of a generally funded program to hire a sign language interpreter and emphasizing the neutral nature of
} the program and the role of private choice in use of funds).

46. 474 U.S. 481 (1986).

47. Id. 
genuinely independent and private choices of aid recipients." ${ }^{48}$ Also central to the decisions was that the aid was " made available generally without regard to the sectarian-nonsectarian, or public-nonpublic nature of the institution benefited,' and [was] in no way skewed towards religion., 49

This increasingly accommodationist line of cases reached its apogee in 2002's Zelman v. Simmons-Harris. ${ }^{50}$ Zelman held constitutional an Ohio program allowing parents of children residing in under-performing school districts to receive state funds toward tuition at the public or private school of their choice, including parochial schools. ${ }^{51}$ The Court first found that the program had a valid secular purpose: "providing educational assistance to poor children in a demonstrably failing public school system." ${ }^{52}$ Relying on Mueller, Witters, and Zobrest v. Catalina Foothills School District, ${ }^{53}$ the Court held,

where a government aid program is neutral with respect to religion, and provides assistance directly to a broad class of citizens who, in turn, direct government aid to religious schools wholly as a result of their own genuine and independent private choice, the program is not readily subject to challenge under the Establishment Clause.

The Court further held that whether the majority of funds would inevitably reach religious institutions was constitutionally irrelevant. ${ }^{55}$ In a concurring opinion, Justice O'Connor reconciled the holding with Everson, arguing that a fair reading of Everson clarifies the notion that governmental programs that aid religious education must flow through the hands of the individual recipients. ${ }^{56}$ Everson, after all, did uphold the transportation reimbursement program. ${ }^{57}$ Zelman represents the current state of Establishment Clause jurisprudence as it relates to public educational funding.

48. Id. at 487 .

49. Id at $487-88$ (quoting Comm. for Pub. Educ. \& Religious Liberty v. Nyquist, 413 U.S. $756,782-83$, n.38 (1973)).

50. 536 U.S. 639.

51. Id.

52. Id. at 649 .

53. 509 U.S. 1.

54. Zelman, 536 U.S. at 652 .

55. Id. at 658 .

56. Id. at 669-70 (O'Connor, J., concurring).

57. Id. at 670 


\section{Free Exercise, Smith, and Lukumi}

The general trend in Establishment Clause jurisprudence toward accommodation of religion parallels a similar trend in Free Exercise jurisprudence. This trend is largely due to the interconnected nature of the two clauses. Taking Walz as an example, when the exemption from a general taxation statute is granted to a religious institution without violating the Establishment Clause, a potential burden on the free exercise of that institution correspondingly is removed. A second trend, however, has manifested itself in free exercise jurisprudence in the last fifteen years - namely, greater flexibility in allowing state and local political processes to resolve potential burdens placed on religious exercise by generally applicable laws.

For decades, the test set forth in 1963's Sherbert v. Verner ${ }^{58}$ remained the standard by which impermissible governmental burden of free exercise was evaluated. Sherbert held that a person discharged from a job because of a refusal to work on the Sabbath could not be denied unemployment benefits. ${ }^{59}$ Rather than merely allowing states to argue an advancement of secular goals, Sherbert held that "any incidental burden on the free exercise of [an individual's] religion may be justified by a "compelling state interest in the regulation of a subject within the [s]tate's Constitutional power to regulate.",60 This compelling state interest test was a strict one: "no showing merely of a rational relationship to a colorable state interest would suffice; in this highly sensitive constitutional area, 'only the gravest abuses, endangering paramount interests, give occasion for permissible limitation." "61 The state wishing to limit free expression would be required "to demonstrate that no alternative forms of regulation" were available to advance the asserted state interest "without infringing First Amendment rights." 62

The Sherbert test, with its implied distrust of local political processes in protecting free exercise rights, was applied over the next several decades in cases involving denial of unemployment benefits, ${ }^{63}$ as well as

58. 374 U.S. 398 (1963).

59. Id.

60. Id. at 403 (quoting NAACP v. Button, 371 U.S. 415, 438 (1963))

61. Id. at 406 (quoting Thomas v. Collins, 323 U.S. 516, 530 (1945)).

62. Id. at 407 .

63. See, e.g., Hobbie v. Unemployment Appeals Comm'n, 480 U.S. 136 (1987) (holding that Florida's denial of unemployment compensation to an individual fired for refusing to work on the Sabbath violated her First Amendment right); Thomas v. Review Bd., 450 U.S. 707 (1981) (holding that Indiana's denial of unemployment compensation to an individual who quit his job because his religious beliefs prevented him from making war materials violated his First Amendment right). 
in a variety of other fields. ${ }^{64}$ The preeminence of the Sherbert test, as well as the Court's corresponding requirement of what later was characterized as "strict scrutiny" 65 of the compelling state interest in burdening free exercise, was transformed by 1990's Employment Division, Department of Human Resources of Oregon v. Smith. ${ }^{66}$ The Court by a five-to-four majority reversed the Oregon Supreme Court, which had held that the denial of unemployment benefits to persons discharged as a result of a religious use of peyote violated the Free Exercise Clause. ${ }^{67}$ Justice Scalia, writing for the majority, made the following statement:

The only decisions in which [the Court has] held that the First Amendment bars application of a neutral, generally applicable law to religiously motivated action have involved not the Free Exercise Clause alone, but the Free Exercise Clause in conjunction with other constitutional protections, such as freedom of speech and of the press. ${ }^{68}$

The majority then held the Sherbert compelling interest test inapplicable to free exercise analysis. ${ }^{69}$ According to the majority, the Court had only three times used the Sherbert test to invalidate unemployment rules that "conditioned ... benefits upon an applicant's willingness to work under conditions forbidden by his religion." Further, the Court had "never invalidated any governmental action on the basis of Sherbert" in other contexts. ${ }^{71}$ The Court found Sherbert inapplicable to criminal law in general, ${ }^{72}$ and held that the compelling state interest test was completely inapplicable to free exercise jurisprudence. ${ }^{73}$ The Court asserted that the use of the compelling state interest test, while applicable to other constitutional areas such as racial discrimination or free speech, "is not remotely comparable... for the

64. See, e.g., United States v. Lee, 455 U.S. 252 (1982) (holding that the government's interest in collecting social security tax outweighed the burden placed on an Amish farmer with a religious objection to payment of the tax); Gillette v. United States, 401 U.S. 437 (1971) (holding the government's use of a military draft to be a compelling state interest outweighing burdening conscientious objectors' religious beliefs).

65. See, e.g., Hobbie, 480 U.S. at 141 (noting that case law, including Sherbert, required that indirect infringements on religious liberty be subjected to strict scrutiny).

66. 494 U.S. 872 (1990).

67. Id.

68. Id. at 881 .

69. Id. at $882-86$.

70. Id. at 883 .

71. Id.

72. Id. at 884 .

73. Id. at $885-86$. 
purpose asserted here. What it produces in those other fields - equality of treatment and an unrestricted flow of contending speech-are constitutional norms; what it would produce here-a private right to ignore generally applicable laws - is a constitutional anomaly." ${ }^{, 74}$ After Smith, facially neutral laws that burden religious practice need not be justified by a compelling governmental interest if they are of general applicability. The essence of this "neutrality principle," in its strictest conception, is that neutral laws that incidentally burden religion are constitutionally acceptable under the Free Exercise Clause. ${ }^{75}$

Smith's new neutrality principle understandably threw free exercise jurisprudence into confusion, and many observers worried that the Court's newly minted deference to state legislatures indicated a willingness to accept a state's assertion of neutrality at face value. ${ }^{76}$ Three years later, Church of the Lukumi Babalu Aye, Inc. v. City of Hialeah $^{77}$ clarified the Court's new standard of free exercise review. The case involved a community that had banned ritual sacrifice of animals in response to an influx of practitioners of Santeria, a religious group whose rites included such ritual sacrifice. ${ }^{78}$ While reaffirming the Smith standard, the Court in Lukumi emphasized that "the minimum requirement of neutrality is that a law not discriminate on its face." The Court went further, demonstrating a willingness to examine the actual effect of a statute and to examine the legislative record to determine whether the enactment of the statute was motivated by the intent to suppress a particular religious belief. ${ }^{80}$ Noting that the Free Exercise Clause “"forbids subtle departure from neutrality' and 'covert suppression of particular religious beliefs," burdening religious practice that is not neutral or of general application

74. Id. at 886

75. See id. at 878 (discussing the validity of a tax that only incidentally prohibits the exercise of religion). The Establishment Clause parallel to this free-exercise neutrality principle can be seen in the Zelman decision; that is, neutral laws that incidentally burden religion are constitutionally acceptable under the Establishment Clause. Zelman v. Simmons-Harris, 536 U.S. 639, 652 (2002). Thus, the neutrality principle might be stated in this way: neutral, generally applicable laws which incidentally benefit or burden religious exercise are constitutionally permissible under both clauses.

76. See, e.g., Michael W. McConnell, Free Exercise Revisionism and the Smith Decision, 57 U. CHI. L. REV. 1109, 1133 (1990) (discussing Smith's characterization of generally applicable laws as presumptively neutral).

77. 508 U.S. 520 (1993).

78. Id.

79. Id. at 533

80. Id. at 534-35.

81. Id. at 534 (quoting respectively Gillette v. United States, 401 U.S. 437, 452 (1971); Bowen v. Roy, 476 U.S. 693, 703 (1986)). 
must undergo the most rigorous of scrutiny." 82 Lukumi thus appeared to reaffirm the Court's commitment to the neutrality principle stated in Smith, but at the same time to reaffirm its commitment to protection in cases of obvious religious discrimination. ${ }^{83}$

\section{E. Locke v. Davey}

\section{Factual and Procedural Background}

In late 2003, the Supreme Court heard arguments in a case considered vitally important by both opponents and proponents of allowing public funds to be used for religious education purposes. ${ }^{84}$ Zelman had cleared the way to allow state educational funding schemes to include religious schools, but the question remained whether such inclusion was mandatory.

The Washington State Legislature established the Promise Scholarship Program, ${ }^{85}$ which allowed Washington high-school seniors who met eligibility requirements to receive a two-year, post-secondary scholarship. ${ }^{86}$ These eligibility requirements included academic, income, and enrollment requirements. ${ }^{87}$ The enrollment requirements provided that the scholarship money could not be used for students pursuing a

82. Id. at 546 .

83. See, e.g., Stephen L. Carter, The Resurrection of Religious Freedom?, 107 HARV. L. REV. 118,141 (1993) (arguing that after the Court's seeming abandonment of free exercise protection in Smith, Lukumi suggests that "the Supreme Court is willing, at a minimum, to set aside efforts to make religions suffer special penalties that secular organizations do not"). But see Renee Skinner, The Church of the Lukumi Babalu Aye, Inc. v. City of Hialeah: Still Sacrificing Free Exercise, 46 BAYLOR L. REV. 259, 277 (1994) (arguing that Lukumi merely limits a further expansion of the Smith doctrine, but does not fundamentally affect Smith's consequences). Additionally, an obvious parallel exists with the Court's willingness to protect against racial discrimination where provable "discriminatory intent" exists. See, e.g., Washington v. Davis, 426 U.S. 229, 240-41 (1976) (holding that "the invidious quality of a law claimed to be racially discriminatory must ultimately be traced to a racially discriminatory purpose," but that this does not necessarily imply that "the necessary discriminatory racial purpose must be express or appear on the face of the statute.").

84. See Linda Greenhouse, Justices Resist Religious Study Using Subsidies, N.Y. TIMES, Dec. 3, 2003, at A1.

85. Locke v. Davey, 540 U.S. 712, 715 (2004).

86. Id. at 715-16.

87. The eligibility requirements stated,

[a] student must graduate from a Washington public or private high school and either 1,200 graduate in the top $15 \%$ of his graduating class, or attain on the first attempt a cumulative score of or better on the Scholastic Assessment Test I, or a score of 27 or better on the American College Test. The student's family income must be less than $135 \%$ of the State's median. Finally, the student must enroll at least half-time in an eligible postsecondary institution in the state of Washington.

Id. at 716 (internal quotations and citations omitted). 
degree in theology. ${ }^{88}$ Although the statute did not explicitly define "a degree in theology," both parties in the case conceded that "the statute simply codifies the State's constitutional provision on providing funds to students to pursue degrees that are devotional in nature or designed to induce religious faith." 89

Joshua Davey was a Promise Scholarship recipient who enrolled in Northwest College, "a private, Christian college affiliated with the Assemblies of God denomination, and ... an eligible institution under the Promise Scholarship Program." major in business management/administration and pastoral ministries, with the specific object of training for a religious ministry. ${ }^{91} \mathrm{He}$ was denied his scholarship funds when he refused to certify that he was not using the funds to pursue a degree in devotional theology. ${ }^{92}$

Davey filed a federal civil rights action in the District Court for the Western Division of Washington under 42 U.S.C. $§ 1983^{93}$ seeking both damages and to enjoin the State from refusing him his scholarship funds. ${ }^{94}$ Davey alleged that the State of Washington violated "the Free Exercise, Establishment, and Free Speech Clause of the First Amendment." 95 The district court refused to grant an injunction and granted summary judgment in favor of the State. ${ }^{96}$

A divided panel of the Ninth Circuit reversed the district court's grant of summary judgment on appeal, holding that "the State had singled out religion for unfavorable treatment and thus under ... Church of the Lukumi Babalu Aye, Inc. v. Hialeah, the State's exclusion of theology majors must be narrowly tailored to achieve a compelling state interest." Rejecting Washington's antiestablishment claims as

88. Id.

89. Id. (internal quotations omitted).

90. Id. at 717 .

91. Id.

92. Id.

93. 42 U.S.C. $§ 1983$ (2000) authorizes a civil action for deprivation of rights against every person "who, under color of any statute, ordinance, regulation, custom, or usage, of any State or Territory or the District of Columbia, subjects, or causes to be subjected, any citizen of the United States or other person within the jurisdiction thereof to the deprivation of any rights, privileges, or immunities secured by the Constitution and laws."

94. Davey v. Locke, No. C00-61R, 2000 U.S. Dist. LEXIS 22273, at*4 (W.D. Wash. Oct. 5, 2000), rev'd, 299 F.3d 748 (9th Cir. 2002), rev'd, 540 U.S. 712 (2004).

95. Locke, 540 U.S. at 718.

96. Davey, 2000 U.S. Dist. LEXIS 22273, at*4, *26.

97. Locke, 540 U.S. at 718 (citation omitted). 
uncompelling, the appellate court held the Promise Scholarship Program unconstitutional. $^{98}$

\section{Majority Opinion}

Chief Justice Rehnquist, writing for the seven-justice majority, began by noting that the Establishment Clause and the Free Exercise Clause are frequently in tension, but that there is, as the Court had previously noted in Walz v. Tax Commission, "some room for play in the joints" between the two clauses. ${ }^{99}$ The majority first dismissed the Establishment Clause issue, noting that should Washington's program not wish to exclude theology students, this would be constitutionally permissible after Zelman, ${ }^{100}$ as the link between government funds and religious training was broken by individual choice of the recipient. ${ }^{101}$

Turning to the free exercise issue, ${ }^{102}$ the majority dismissed the argument that, after $L u k u m i,{ }^{103}$ the Washington program was not facially neutral and therefore was presumptively unconstitutional and subject to the strictest scrutiny. ${ }^{104}$ The majority first noted that any potential discrimination by the Promise Scholarship Program or the State of Washington would be of a much milder kind than in Lukumi, which imposed criminal sanctions on Santeria practitioners and essentially denied them a political voice in the community. ${ }^{105}$ The exclusion of theology majors from the Promise Scholarship program was characterized as a "State merely [choosing] not to fund a distinct category of instruction.", 106

The majority then addressed Justice Scalia's dissent. Justice Scalia argued that because Washington chose to fund training for all secular professions, it had to do so for religious professions as well; the majority held this reasoning to be flawed for several reasons. ${ }^{107}$ First, the majority was not willing to accept the contention that religious education and secular education were at all equivalent. The two types of education are

\footnotetext{
98. Davey, 299 F.3d at 760.

99. Locke, 540 U.S. at 718 (citing Walz v. Tax Comm'n, 397 U.S. 664, 669 (1970)).

100. Zelman v. Simmons-Harris, 536 U.S. 639, 652 (2002).

101. Locke, 540 U.S. at 719.

102. Davey's free speech argument was dismissed in a footnote: "the Promise Scholarship Program is not a forum for speech." Id. at 720 n.3.

103. Church of the Lukumi Babalu Aye, Inc. v. Hialeah, 508 U.S. 520 (1993).

104. Locke, 540 U.S. at 720.

105. Id. at $720-21$.

106. Id. at 721 .

107. Id.
} 
simply "not fungible," one major distinction being that "majoring in devotional theology is akin to a religious calling as well as an academic pursuit." 108 Second, the court examined the motive behind the statutory exclusion, concluding that Washington's choice to treat religious education separately was a product of traditional views on religion- "in favor of free exercise, but opposed to establishment"-rather than evidence of any hostility or animus toward religion. ${ }^{109}$

The majority then turned briefly to the historical background of the Establishment Clause, particularly noting popular uprisings against using taxes to fund church leaders, and that many states, prior to the enactment of the Constitution, had provisions in their state constitutions forbidding using public funds to support clergy. ${ }^{110}$ Early state governments had no problem preventing churches alone from receiving state funds, and thus, historically, there existed a substantial state interest in states preventing the funding of religion or of religious education. ${ }^{111}$

The majority further distinguished the facts of Lukumi from the Promise Scholarship Program: "Far from the hostility towards religion which was manifest in Lukumi, we believe that the entirety of the Promise Scholarship Program goes a long way towards including religion in its benefits." 112 This inclusion was evidenced by the ability of Promise Scholars to attend predominantly religious schools. The Court also noted that the program allowed students to take devotional theology courses - they simply could not pursue degrees in devotional theology. ${ }^{113}$

The majority concluded that, given the historical and substantial state interest in preventing public funds from reaching religion or religious education, coupled with the slight burden placed on Davey, "[i]f any room exists between the two religion clauses, it must be here."114 The Court thus reversed the decision of the Ninth Circuit. ${ }^{115}$

\section{Dissent}

Justice Scalia, joined by Justice Thomas, dissented from the majority opinion. The dissent opened by invoking the general agreement in

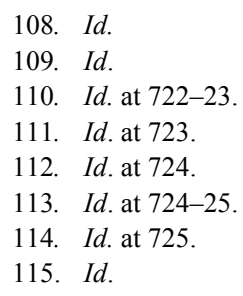


Lukumi that "formal neutrality' is a 'necessary conditio[n] for freeexercise constitutionality," "and argued that the majority opinion could not be reconciled with that statement. ${ }^{116}$

Justice Scalia argued that the principle governing the case reached back to Everson, particularly the language holding that a state " cannot exclude ... members of any . . faith, because of their faith, or lack of it, from receiving the benefits of public welfare legislation.""117 Justice Scalia characterized the Promise Scholarship Program as such a public welfare legislation program, arguing that

[w]hen a state makes a public benefit generally available, that benefit becomes part of the baseline against which burdens on religion are measured; and when the State withholds that benefit from some individuals solely on the basis of religion, it violates the Free Exercise Clause no less than if it had imposed a special tax. ${ }^{11}$

In Justice Scalia's view, Davey was not asking for special treatment, but merely equal treatment: he wanted to be allowed to do what all other Promise Scholars were allowed to do. ${ }^{119}$

The discussion of public benefit programs was further employed to distinguish the majority's historical argument: the case did not involve laws singling out ministers for benefits, rather it involved public benefit programs generally available to a broad segment of the population. ${ }^{120}$ Justice Scalia conceded the Framers' hostility to specifically funding religion, but he argued that this did not necessarily mean they were hostile to allowing ministers to take part in general publicly funded programs - using public roads on the way to church, for example. ${ }^{121}$

Justice Scalia then attacked the majority's reliance on "play in the joints" as a spurious concept, drawing an analogy to racial discrimination cases:

116. Id. at 726 (Scalia, J., dissenting) (quoting Church of the Lukumi Babalu Aye, Inc. v. Hialeah, 508 U.S. 520, 546, 563 (1993)).

117. Id. (quoting Everson v. Bd. of Ed., 330 U.S. 1, 16 (1947)).

118. Id. at 726-27. But see the Court's characterization of other denial-of-benefit cases in Maher v. Roe, 432 U.S. 464, 464 (1977) (noting the substantial distinction between a denial of benefits that would ease the exercise of a right and a direct burden on the right itself), and Sullivan $v$. Rust, 500 U.S. 173, 173 (1991) (characterizing a denial of welfare benefits conditioned on nondiscussion of abortion as merely a matter of governmental funding priorities), as discussed infra notes $159-63$ and accompanying text.

119. Locke, 540 U.S. at 727 (Scalia, J., dissenting).

120. Id.

121. Id. at $727-28$. 
A municipality hiring public contractors may not discriminate against blacks or in favor of them; it cannot discriminate a little bit each way and plead "play in the joints" when haled into court. If the Religion Clauses demand neutrality, we must enforce them, in hard cases as well as easy ones. 122

In any event, he argued, play in the joints, even if valid, should only be used in close cases, and the unanimous decision in Witters clearly showed that this case was not close. ${ }^{123}$ Should the majority insist on some play in the joints, there were any number of ways the Promise Scholarship Program could be held nondiscriminatory: Washington could make the scholarship redeemable only at public universities, where the State set the curriculum; it could make the scholarship redeemable only for select courses of study; or it could end the program entirely. ${ }^{124}$

Justice Scalia then questioned the nature of the asserted State interest itself, first classifying it as so broadly defined that "it would be offended by a program with such an incidental, indirect religious effect." ${ }^{25} \mathrm{He}$ then classified the state interest as "a pure philosophical preference" that the citizens of Washington would somehow have their freedom of conscience violated by allowing theology students to share in the scholarship program. ${ }^{126}$ He noted that such a choice logically could be extended to exclude religion from any state program whatsoever, and pointed out that such an interest was, in any event, not classified by the majority as compelling, as "the [majority] opinion is devoid of any mention of standard of review." 127

The heart of the dissent was Justice Scalia's contention that "[ $t]$ he Court makes no serious attempt to defend the program's neutrality, and instead identifies two features thought to render its discrimination less offensive;" that is, by pointing out the lightness of Davey's burden and the lack of any motive for the Washington Legislature to discriminate. ${ }^{128}$ In the dissent's view, the majority was imposing some sort of "threshold quantum-of-harm requirement" on a case involving a statute arguably discriminatory on its face, which, it was noted, had never been the Court's policy in deciding cases involving other types of

\footnotetext{
122. Id. at 728 .

123. Id. at 729 .

124. Id.

125. Id.

126. Id. at 730 .

127. Id.

128. Id. at 731
} 
discrimination. ${ }^{129}$ Further, even if there were a threshold, it had clearly been met - the forfeiture of an otherwise available $\$ 3000$ scholarship benefit. ${ }^{130}$

Regarding the lack of motive by the state legislature to discriminate, Justice Scalia argued that motive was irrelevant. "If a State deprives a citizen of trial by jury or passes an ex post facto law, we do not pause to investigate whether it was actually trying to accomplish the evil the Constitution prohibits. It is sufficient that the citizen's rights have been infringed." 131 According to Scalia, when the Court declared racial segregation to be unconstitutional, it did not inquire whether the legislature, in passing segregation statutes, was motivated by a "wellmeaning but misguided belief that the races would be better off apart." Moving away from analogy, the dissent discussed McDaniel v. Paty, ${ }^{133}$ noting that when the Court invalidated a statute prohibiting members of the clergy from sitting in the state legislature, it took the good intentions of the state legislature at face value - but still invalidated the statute. ${ }^{134}$

Justice Scalia concluded by arguing that the majority's rationale could be extended indefinitely, to the point of denying priests and nuns prescription drug benefits, or banning religious garb in school, as the French recently did. ${ }^{135}$ "When the public's freedom of conscience is invoked to justify denial of equal treatment, benevolent motives shade into indifference and ultimately into repression. Having accepted the justification in this case, the Court is less well equipped to fend it off in the future." 136

Justice Thomas concurred in Justice Scalia's dissent and added his own short postscript. He wrote that, because the parties both agreed that "degree in theology," as used in the statute meant specifically "a degree in devotional theology," rather than in theology in general (which may contain nonreligious elements), Justice Scalia's application of precedent was correct. ${ }^{137}$ He implied that the reasoning might have been different had "degree in theology" been construed to encompass this wider definition. ${ }^{138}$

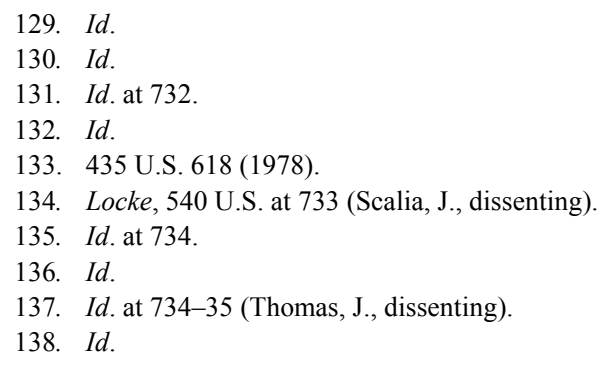




\section{ANALYSIS}

\section{A. Locke and the Zone of State and Local Discretion}

The Supreme Court's ultimate decision in Locke v. Davey, or at least the lopsided nature of the decision, came to some observers as a surprise. ${ }^{139}$ Given the two-decade general trend allowing state educational funds to flow to religious institutions, it would not have been surprising had the Court continued this trend and ruled for Davey. Additionally, one of Justice Scalia's stated objectives in the Smith decision was to avoid carving out religious exceptions to neutral, generally applicable statutes. ${ }^{140}$ Further, the baseline requirement to pass free exercise muster thus seems to be that the statute in question be facially neutral, and Lukumi's holding that a generally applicable law which discriminates against a particular religion should be subjected to strict scrutiny seems to imply that discrimination concerns would, at the least, have played a greater role in the majority's reasoning.

These Establishment Clause trends should not, however, obscure an equally important trend. The general trend in free exercise jurisprudence has been a journey from Sherbert's restrictive compelling interest test to Smith's willingness to trust state and local political processes in assessing neutrality concerns. Until Locke, the Establishment Clause accommodationist trend was able to coexist with the Free Exercise Clause trend providing state and local discretion.

Zelman provides a case in point. Ultimately, Zelman, in the words of Justice Thomas, "allow[s] States greater latitude in dealing with matters of religion and education." 141 Zelman allows states to choose to allow public funds to reach religious schools, subject to few provisos: that the plan be neutral as regards religion; that the plan benefit a broad class of citizens; and that the dispersal of funds ultimately involve private,

139. See, e.g., Rob Boston, Supreme Victory: High Court Thwarts Religious Right Scheme to Require State Funding for Religion, CHURCH \& ST., Apr., 2004, at 4 (expressing surprise at the result in Locke, given the quick disposal of the case and the makeup of the Court); Mike McKee, Justices Say States May Deny Theology Scholarship Funds, Legal InTELLIGENCER, Feb. 27, 2004, at 4 (expressing surprise at the lopsided Locke decision). But see Ira C. Lupu \& Robert W. Tuttle, Hitting the Wall: Religion is Still Special Under the Constitution, Says the High Court, LEGAL TIMES, Mar. 15, 2004, at 68 (arguing that the Locke decision is "no great surprise," given that the majority was comprised of a combination of justices with a history of supporting either a stricter church-state separation or a greater freedom of states from federal oversight).

140. See Employment Div., Dep't of Human Res. v. Smith, 494 U.S. 872, 882 (1990) (declining to hold that if otherwise prohibited conduct is accompanied by religious convictions the conduct is protected).

141. Zelman v. Simmons-Harris, 536 U.S. 639, 680 (2002) (Thomas, J., concurring). 
individual choice. ${ }^{142}$ In other words, the Zelman Court established a minimum threshold for an education aid program. This naturally leads to the implication that, once the threshold is met, federal constitutional muster is passed. By declining to intervene, the Court necessarily affords states great discretion as to how to administer and monitor such funding programs. The direction and uses of educational funds are now largely the province of state legislatures and court systems. By reducing its Establishment Clause concerns to the minimum guidelines set out in Zelman, the implication arises that litigation within the guidelines is likely to be resolved by state law. In essence, the states become the new arbiters of Establishment Clause doctrine, at least as it relates to educational funding.

When viewed in this context, Locke seems less a surprising reversal of the accommodationist trend than it does a continuation of the Court's trend toward allowing greater state freedom in balancing the religious concerns of their own citizens. In the words of one observer, "[r]ead together, Zelman and Locke show significant deference to [state] legislatures ... the first by permitting them to fund religious instruction; the second by permitting them not to." step away from insuring the government's neutrality between religion and secularism, and more a policy of affording state and local political processes a greater say in public religion funding.

The Court in Locke did not explicitly abandon the neutrality requirement, but it certainly stepped away from a more formalistic, absolute rule of strict neutrality. The Locke decision can be seen as the result of a dispute over priorities. Justices Scalia and Thomas assign priority to maintaining the strictness of the no-exceptions neutrality standard set forth in Smith. ${ }^{144}$ The majority, while not abandoning this standard, instead places priority on state and local discretion. ${ }^{145}$ In a sense, the majority creates a mirror image of Zelman. Where Zelman allows an exception from a general burden to pass muster under the Establishment Clause, ${ }^{146}$ Locke allows an exception from a general benefit to pass muster under the Free Exercise Clause. ${ }^{147}$

\footnotetext{
142. Id. at 652 (majority opinion).

143. Richard C. Schragger, The Role of the Local in the Doctrine and Discourse of Religious Liberty, 117 HARV. L. REV. 1810, 1865 (2004).

144. Locke v. Davey, 540 U.S. 712, 731 (2004) (Scalia, J., dissenting).

145. See id. at 712 (majority opinion) (refusing to agree with the argument that the program was unconstitutional because it was not facially neutral).

146. Zelman, 536 U.S. at 640.

147. See Locke, 540 U.S. at 731 (holding that excluding scholarship eligibility for pursuit of theology degree is constitutional).
} 
Taken in conjunction with Zelman, Locke establishes a zone of state and local discretion in publicly funding religious education. Within this zone reside cases in which there exists room for play in the joints between the clauses. While the majority purports to limit its holding to the case at hand, Locke nonetheless has enormous implications. First, regardless of the actual scope of the holding, the Court's methodology used in reaching the holding implicates a number of recent doctrinal developments-including the Court's reluctance to apply Lukumi's strict scrutiny standard or to rely heavily on Smith's neutrality requirement. Second, even if the Locke decision is intended to apply solely within the sphere of religious education, a cursory glance at the last half-century of Religion Clause jurisprudence demonstrates the inseparability of religious education controversies and general church-state controversies. For example, Everson-ostensibly a religious education case-has informed areas as wide-ranging as unemployment benefits ${ }^{148}$ and the public display of religious symbols. ${ }^{149}$ Similarly, the rationale behind Smith - ostensibly an unemployment benefit case- has been extended to inform education cases like Zelman.

In light of Locke's importance, several questions in particular deserve exploration. Does the Court's new emphasis on state and local discretion better serve the purposes of the religion clauses, particularly in regard to discrimination? How, exactly, is the majority's reasoning to be applied, and what is the extent of this zone of discretion? Finally, how have post-Locke cases employed Locke's holdings, and what trends for future litigation do such uses hold?

\section{B. The Potential for Discrimination}

\section{Standards for Determining Locke's Burden Requirement}

Any discussion of the effect of Locke on discrimination must begin with an examination of the standards used by the majority and dissent to evaluate the discrimination suffered, if any, by Davey. Davey claimed (and the dissent agreed) ${ }^{150}$ that Washington was burdening his free exercise rights by denying him access to a general state benefit program

\footnotetext{
148. See, e.g., Sherbert v. Verner, 374 U.S. 398, 410 (1963) (reaffirming Everson's principle that the nature of one's faith is not a proper ground for denying public welfare legislation).

149. See, e.g., County of Allegheny v. ACLU, 492 U.S. 573, 591 (1989) (affirming Everson's summary of the basic principles behind Religion Clause jurisprudence).

150. Locke, 540 U.S. at 727 (Scalia, J., dissenting).
} 
solely on the basis of his religious beliefs. ${ }^{151}$ The majority, however, characterized the burdening of Davey's rights as de minimis, if indeed they were burdened at all. ${ }^{152}$ Davey was not subject to criminal or civil penalties, forced to choose between abandoning his religion and receiving his scholarship, or prevented from using the scholarship at a Christian university. Whether Washington's actions amounted to discrimination, then, rests on the standard used to evaluate the nature of a free exercise burden.

One obvious parallel, and the one most heavily drawn on by Justice Scalia, is that of discrimination that violates the Fourteenth Amendment's equal protection guarantees. Justice Scalia found it astonishing that the majority seemed to accept even a modicum of discrimination as acceptable. ${ }^{153}$ Citing, among other cases, Brown v. Board of Education, ${ }^{154}$ he wrote that "[t]he indignity of being singled out for special burdens on the basis of one's religious calling is so profound that the concrete harm produced can never be dismissed as insubstantial. The Court has not required proof of 'substantial' concrete harm with other forms of discrimination." 155 He further argued that consideration of potential motivations, including animus toward religion, was completely misplaced, noting that in race discrimination cases the Court did not pause to consider whether segregation laws may have been wellmeaning. ${ }^{156}$

This argument, if one finds persuasive the parallel between equal protection and religious discrimination cases, is quite persuasive. The argument becomes even more attractive because of the majority's failure to directly acknowledge it. This is one of the great weaknesses of the majority's opinion, as is its failure to explicitly suggest another paradigm by which to evaluate the nature of Davey's burden. Had the majority chosen to address the dissent's argument, it would have had ample precedent with which to contest Justice Scalia's contention.

One possible parallel, for example, can be drawn to abortion rights. The Court wrote in Maher v. Roe that "Roe [v. Wade] did not declare an unqualified 'constitutional right to an abortion' .... Rather, the right protects the woman from unduly burdensome interference with her

\footnotetext{
151. Id. at 718 (majority opinion).

152. Id. at 725 .

153. See id. at 731 (Scalia, J., dissenting) (arguing that religious discrimination on the face of a statute cannot be insubstantial).

154. 347 U.S. 483 (1954).

155. Locke, 540 U.S. at 731 (2004) (Scalia, J., dissenting).

156. Id. at 732 .
} 
freedom to decide whether to terminate her pregnancy."157 Maher's parallel to the Free Exercise Clause is readily apparent. Just as the Free Exercise Clause does not grant an absolute right to any practice deemed religious (e.g., polygamy or illegal peyote use), it does protect against unduly burdensome governmental interference with free religious exercise. ${ }^{158}$ The Maher Court held constitutional a Connecticut Medicare program for indigents that only funded medically necessary abortions. ${ }^{159}$ It relied heavily on the notion that a denial of benefits that would ease the exercise of a right differs substantially from a direct burden on the right itself. The Court wrote,

[t]here is a basic difference between direct state interference with a protected activity and state encouragement of an alternative activity consonant with legislative policy. Constitutional concerns are greatest when the State attempts to impose its will by force of law; the State's power to encourage actions deemed to be in the public interest is necessarily far broader. ${ }^{160}$

Maher stands for the proposition that, at least within the abortion rights context, a denial of a benefit should not necessarily be viewed as a burden on a constitutionally protected right.

It is tempting to reject the parallel to abortion rights as inapt, given the long acceptance of religious freedom rights compared to the relatively short recognition of abortion rights. It is, however, illuminating that the Maher reasoning has been extended to a discussion of First Amendment rights. In Sullivan v. Rust, a health program that provided local health clinics funding on the condition that recipient clinics not discuss abortion as a family-planning option was challenged as an impermissible burden on free speech rights. ${ }^{161}$ In upholding the program, the five-to-four majority (joined by Justice Scalia) noted that the Maher Court "rejected the claim that ... unequal subsidation worked a violation of the Constitution." "162 The majority characterized the speech restrictions as part of a program where the government "has merely chosen to fund one activity to the exclusion of the other." "163 These words, incidentally, are similar to those Chief Justice Rehnquist used in

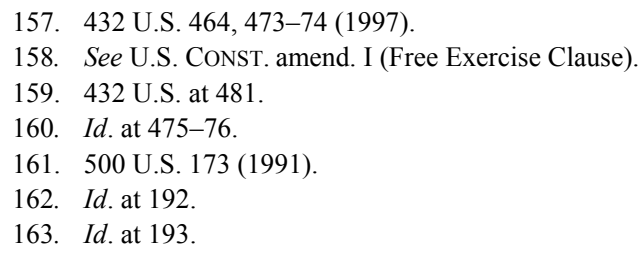


describing the Washington scholarship exclusion for the Locke majority. ${ }^{164}$ On its face, Justice Scalia's acceptance of the characterization of the medical benefits in Sullivan contrasts with his characterization of the benefits at issue in Locke: "When the State makes a public benefit generally available, that benefit becomes part of the baseline against which burdens on religion are measured."165

Additionally, Justice Scalia's plurality opinion in Capitol Square Review \& Advisory Board v. Pinette, ${ }^{166}$ held that the state could not prohibit the display by a private organization of a cross on a state-created public forum on Establishment Clause grounds where "the forum created by the State was open to a broad spectrum of groups and would provide only incidental benefit to religion."167 In the words of one observer,

[t] he plurality refused to evaluate whether the placement constituted an endorsement on the facts by concluding that allowing access to a public forum is inherently "neutral" and any benefit to religion is purely incidental. ... [I]f the government did not intend to send a message of endorsement, it is irrelevant that a message of endorsement was received.

The majority applied this reasoning to the burden/free exercise side of the equation in Locke, where the scholarship program was open to a broad spectrum of groups, where it would only incidentally burden religious free exercise, and where there was no government intent of animus toward religion.

The fundamental conflict in Locke can thus be seen as a question of whether Davey's burden should be evaluated from an equal protection standpoint, or whether it should follow the benefit-burden view of discrimination subscribed to by the Court in other civil rights cases. The equal protection parallel is attractive in that it seems to err on the side of the protection of individual religious expression, but ultimately it seems a poor fit. Equal protection arguments tend to apply when smaller, less politically powerful groups are unlikely to be able to ensure for themselves equal protection under the law. ${ }^{169}$ Had the Washington

\footnotetext{
164. See Locke v. Davey, 540 U.S. 712, 721 (2004) ("The state has merely chosen not to fund a distinct category of instruction.").

165. Id. at 726 (Scalia, J., dissenting).

166. 515 U.S. 753 (1995).

167. Id. at 763 .

168. Richard E. Levy, Dueling Values: Balancing Competing Constitutional Interests in Pinette, 5 KAN. J.L. \& PUB. POL'Y 43, 45 (1996).

169. See, e.g., Mass. Bd. of Ret. v. Murgia, 427 U.S. 307, 313-14 (1976) (declining to apply strict scrutiny to age discrimination, in part on grounds that the aged as a class have not suffered a
} 
statute refused to fund, for example, Muslim education specifically, the equal protection argument would certainly apply. However, the claim that religion as a whole is a politically disadvantaged group is difficult to sell. The impact of religious organizations on recent elections at all levels belies this notion. ${ }^{170}$ Additionally, there has been little Court discussion of treating religious persons on the whole as a suspect class, ${ }^{171}$ the traditional trigger for the strict equal protection scrutiny the Locke dissent advocates. ${ }^{172}$ The Court, in numerous contentious constitutional areas, has had little trouble in treating the denial of a benefit as less odious than an actual direct burden on the exercise of a right. The majority seems to stand on firmer ground than the dissent here, though it might have stated its position more forcefully.

\section{Clauses in Tension}

Even absent a showing of discrimination in Davey's case, arguments can be made that the intellectual framework employed by the majority in reaching its decision, both alone and in combination with other precedent, might at least increase the potential for future religious discrimination. Another crucial difference in philosophy between the positions advocated by the Locke majority and the dissent are the respective approaches to the resolution of cases in which the two religion clauses are particularly in tension. Justice Scalia would have the Court continue its role as arbiter of such disputes; that is, adhere to the strict neutrality requirement. The majority would delegate that role, at least some of the time, to state and local governments to allow some departure from the strict neutrality requirement. This naturally requires exploration as to whether increased state and local discretion will lead to an increased opportunity for religious discrimination.

In close cases such as Locke, any decision arguably will violate one or the other clause to some extent. Generally speaking, by holding the

history of mistreatment on account of their age, nor have they "been subjected to unique disabilities on the basis of stereotyped characteristics not truly indicative of their ability"); see also ERWIN CHEMERINSKY, CONSTITUTIONAL LAW 642 (2001) (summarizing the arguments that strict scrutiny is not the proper standard with which to evaluate gender discrimination, especially given that women cannot be considered a politically powerless minority).

170. See, e.g., Michael Cornfield, The Congregation Factor, CAMPAigns \& Elections, Dec. 2004, at 73, 73 (arguing that while the political clout of religious conservatives is sometimes overstated, their impact on the 2004 elections was significant).

171. The Court has, however, on at least one occasion suggested that discrimination against religiousness (as opposed to a particular religion) may call for a "more searching judicial inquiry" into equal protection claims. See United States v. Carolene Prods., 304 U.S. 144, 152 n.4 (1938).

172. See, e.g., Murgia, 427 U.S. at 313 (declining to treat the aged as a suspect class). 
Washington statute constitutional, the majority burdened Davey's free religious exercise, at least to a small extent. If it had held the statute unconstitutional, Washington's antiestablishment concerns, as expressed in its state constitution, would have been implicated, at least to a small extent. What the Locke majority seemed to implicitly acknowledge was that the Court is no better equipped than a state legislature to determine which clause should be affected.

In this sense, allowing state and local governments to decide the matter will not increase the possibility of discrimination any more than would allowing the Court to draw a constitutional line. State governments are more likely to be responsive to local concerns, and they are more likely to possess the advantage of being more politically accountable than the federal judiciary. From a practical standpoint, this responsiveness and political accountability may cut both ways. Some commentators have argued that the threat from, for example, racial discrimination is greater at a state and local level. ${ }^{173}$ Some, however, have argued that centralized restrictions on how states may or must combat racial discrimination has an adverse affect on minorities; ${ }^{174}$ others, that "decentralized government is a structural component of religious liberty." 175 Although such arguments are inevitable in a federal system (and probably will never be definitively settled), they serve to highlight, at the least, that discrimination may potentially emanate from both the national and local levels.

173. See, e.g., Richmond v. J.A. Croson Co., in which Justice Scalia, in a concurring opinion, wrote that "racial discrimination against any group finds a more ready expression at the state and local than at the federal level." 488 U.S. 469, 523 (1989) (Scalia, J., dissenting). He quoted James Madison:

The smaller the society, the fewer probably will be the distinct parties and interests composing it; the fewer the distinct parties and interests, the more frequently will a majority be found of the same party; and the smaller the number of individuals composing a majority, and the smaller the compass within which they are placed, the more easily will they concert and execute their plan of oppression. Extend the sphere and you take in a greater variety of parties and interests; you make it less probable that a majority of the whole will have a common motive to invade the rights of other citizens; or if such a common motive exists, it will be more difficult for all who feel it to discover their own strength and to act in unison with each other.

Id. (quoting THE FEDERALIST No. 10, at 82-84 (Clinton Rossiter ed. 1961)).

174. See, e.g., Lisa E. Chang, Remedial Purpose and Affirmative Action: False Limits and Real Harms, 16 YALE L. \& POL'Y REV. 59, 91-92 (1997) (arguing that Supreme Court mandated restrictions on affirmative action programs discourage minority participation in the political process, harming the interests of the government and the governed).

175. See Schragger, supra note 143, at 1820--31 (arguing that "the dispersal of authority is an independent institutional check on religious favoritism" and that national-level religious legislation might therefore be a greater threat to religious liberty than localized discrimination). 
Viewed from this theoretical perspective, the Locke dissent's approach would seem to offer no definitive advantage over the majority's approach in preventing discrimination, but only to offer different advantages and disadvantages. Further, the majority does not seek to eliminate its role in the review of religion cases altogether, and thereby to abandon free exercise oversight entirely, but merely to expand the boundaries of acceptable state and local behavior to a marginally greater extent.

\section{Boundaries of the Zone of Discretion}

This does, however, bring to light perhaps the greatest weakness of the majority opinion: its failure to delineate boundaries to this newly created zone of state and local discretion. The dissent notes that the Locke "holding is limited to training the clergy, but its logic is readily extendible, and there are plenty of directions to go." "Zelman-Locke's complementary other half - sets up minimum standards beyond which states cannot elect to go in funding religious education. Specifically, these include neutrality toward religion and elements of genuine, individual, private choice. ${ }^{177}$ The Locke majority provides no similar guiding principles. As a result, the dissent's hypothetical situation wherein a state "den[ies] priests and nuns their prescription-drug benefits on the ground that taxpayers' freedom of conscience forbids medicating the clergy at public expens[e]," ${ }^{178}$ while seemingly several logical steps away from Davey's situation, was not definitively placed outside the realm of possibility. On this theoretical level, the potential for discrimination is greater when the majority's approach is followed. It must be noted, however, that creating suitable boundaries to state and local discretion in free exercise issues would alleviate this concern.

Of course, there are inherent dangers in granting states increased Religion Clause discretion. Justice Scalia himself, writing for the Smith majority, admitted that "leaving accommodation [of individual religious practices] to the political process will place at a relative disadvantage those religious practices not widely engaged in."179 While this statement applies to the Locke majority approach, the problem is inherent in the entire Smith analysis system. None of the Locke justices suggest

176. Locke v. Davey, 540 U.S. 712, 734 (2004) (Scalia, J., dissenting).

177. Zelman v. Simmons-Harris, 536 U.S. 639, 662 (2002).

178. Locke, 540 U.S. at 734 (Scalia, J., dissenting).

179. Employment Div., Dep't of Human Res. v. Smith, 494 U.S. 872, 890 (1990). 
abandoning the Smith approach and returning, for example, to the compelling state interest test.

A detailed discussion of the benefits and shortcomings of the Smith approach to free exercise must necessarily be left to the voluminous literature on that case. For purposes of the Locke discussion, however, several points are worth noting. First, again, the Locke dissent's approach would not necessarily provide any more protection against discrimination. ${ }^{180}$ Second, although the dissent claims that the discrimination safeguards set up in Lukumi have all but been ignored, the majority's characterization of its decision as an attempt not to extend Lukumi beyond its logical boundaries is compelling, when taken into account with the majority's view that the Locke question is not one of equal protection, but of denial of benefits. ${ }^{181}$ That is, the Court in Lukumi reaffirmed its commitment to disallow intentionally discriminatory or oppressively burdensome legislation, while allowing states to set their own policies without fear of a flood of litigation resulting from incidental or de minimis free exercise burdens, a sensible course.

Importantly, neither side is abandoning Lukumi altogether. The majority opinion indicates that the Court will continue to apply strict scrutiny where religious exercise becomes subject to civil or criminal penalties, or where it is grounds for exclusion from the political process. $^{182}$ Additionally, it is difficult to see where a state or local government can provide a nondiscriminatory justification for burdening a particular religion, rather than religion generally. Rather than weakening the Lukumi safeguards against discrimination, the Court merely declines to extend their application into a gray area, an area where discrimination might not even have occurred.

\section{The World After Locke}

Logically, one would expect the most immediate consequence of the Locke decision to be the stifling of school funding litigation prompted by the Zelman decision, including those suits brought by parties to force states to allow public educational funding to be made available to students who wish to attend parochial schools, as well as those by parties trying to resurrect state voucher-type programs previously declared by

\footnotetext{
180. See discussion supra Part III.B.2.

181. See discussion supra Part III.B.1.

182. See Locke, 540 U.S. at 720 (rejecting presumptive unconstitutionality because the state's disfavor of religion "imposes neither criminal nor civil sanctions").
} 
state courts to violate state constitution establishment clauses. This has occurred to a certain extent.

As an example, the First Circuit already has decided such a case in Eulitt ex rel Eulitt v. Maine, Department of Education. ${ }^{183}$ The court was asked to revisit an earlier decision ${ }^{184}$ in which it had held that Maine could properly exclude parochial schools from public funding programs without being subject to an equal protection challenge under the Establishment Clause. ${ }^{185}$ Two members of the appellate panel, in deciding the earlier case, indicated that reconsideration might be proper if their understanding of the Establishment Clause proved to be erroneous. ${ }^{186}$ On reconsideration, the appellate court ruled that, under their reading "the [Locke] decision ... recognized that state entities, in choosing how to provide education, may act upon their legitimate concerns about excessive entanglement with religion, even though the Establishment Clause may not require them to do so," and refused to overturn the earlier decision. ${ }^{187}$ Locke also had a strong influence on similar decisions in a federal district court in Florida ${ }^{188}$ and in a second First Circuit decision, this time involving the Massachusetts state constitution. $^{189}$

However, the failure of the Locke Court to provide any standards as to how far a state may stray from strict neutrality, as well as its failure to define the precise limitation of Locke's scope, has, in at least one case, merely altered the approach that such school-voucher litigants have taken. In Bush v. Holmes, ${ }^{190}$ the State of Florida had argued before the Florida Court of Appeals that if a constitutional provision prohibiting aid to religious institutions invalidated the voucher program, then that provision discriminated, in violation of the Free Exercise Clause, against

183. 386 F.3d 344 (1st Cir. 2004).

184. Strout v. Albanese, 178 F.3d 57 (1st Cir. 1999).

185. Eulitt, 386 F.3d at 348.

186. Id.

187. Id. at 355 .

188. Children A \& B, ex rel, Cooper v. Florida, 355 F. Supp. 2d 1298 (N.D. Fla. 2004), aff'd, 140 F. App'x 845 (11th Cir., July 20, 2005) (holding that children have no constitutionally based rights to publicly funded religious education).

189. Wirzburger v. Galvin, 412 F.3d 271 (1st Cir. 2005). The court upheld a district court decision that Massachusetts state constitutional provisions disallowing the use of public initiatives to amend the state constitutional prohibition on public funds going toward religious education did not violate the Free Exercise Clause. The district court cited Locke in reaching its decision, noting that the constitutional provisions, like those of the Washington scholarship program, did not deny citizens a voice in the political affairs of the community nor force religious persons to choose between exercising their religion and receiving a benefit. Id. at 280-81.

190. 886 So. 2d 340 (Fla. Dist. Ct. App. 2004) (en banc). 
voucher recipients who preferred religious schools. ${ }^{191}$ The Florida Court of Appeals, citing Locke, held that the Federal Free Exercise Clause did not prohibit the Florida Constitution from espousing a stricter line regarding public funding reaching religious schools, but certified the question to the Florida Supreme Court, which has yet to address it. ${ }^{192}$

The State, in its brief to the Florida Supreme Court, argued that Locke was restricted to its facts. It distinguished the Opportunity Scholarship Program in that, unlike the Florida program, the Washington program at issue in Locke was inclusive of religious institutions - that is, the money could be used at religious colleges and universities - but was constitutional only insofar as the only exception contained in the program was for the study of devotional theology. ${ }^{193}$ Florida argued that invalidating the Florida program, by contrast, would prohibit all money from reaching public schools; this, arguably, places the Florida provision well outside Locke's narrow prohibition and into Lukumi's strict scrutiny territory. ${ }^{194}$ This argument again highlights Locke's great flaw-the inability or unwillingness to set outer limits as to its central holding. Thus, such litigation seeking to force states to allow public funds to reach parochial institutions is likely to continue, at least until the Court is forced to step in and clarify itself.

A second, perhaps more intriguing source of litigation is the use of the Locke holding as a federalist weapon. That is, states attempting to excuse themselves from an obligation imposed on them by the federal government now have a new tool with which to bolster their arguments. The Supreme Court recently decided Cutter v. Wilkinson, ${ }^{195}$ in which such an argument was made. The Sixth Circuit had held that a portion of the Religious Land Use and Institutionalized Persons Act of $2000^{196}$ (RLUIPA) was unconstitutional under the Establishment Clause. ${ }^{197}$ The portion in question forbade states from imposing burdens on the religious exercise of prisoners without a showing of a compelling interest and a showing that it had used the least restrictive means of advancing that interest. ${ }^{198}$ In its brief to the Supreme Court, Ohio argued that the federal

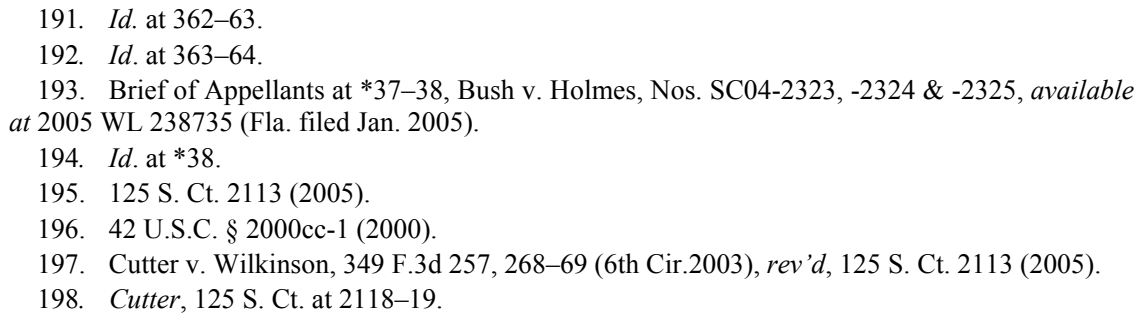


government had overstepped its Establishment Clause authority. ${ }^{199}$ Ohio claimed that Congress required "that States provide religious accommodations in their prisons - accommodations that go beyond those the Constitution requires, and that compromise prison security."200 Further, RLUIPA "is a powerful tool that prisoners advancing religious claims can use to obtain accommodations," as Congress has required that strict scrutiny be applied to claims by prisoners for nonaccommodation. ${ }^{201}$ Interestingly, Ohio argued that, after Locke, the Supreme Court would recognize a "federalist aspect" to the Establishment Clause. ${ }^{202}$ Essentially, "the State has the right to make policy within the 'play in the joints' between the Establishment and Free Exercise clauses, and Congress may not order us to pick a different point in that spectrum." 203 This novel use of the Locke holding exploits the new zone of state discretion set up by the Court.

The Court held RLUIPA constitutional in a unanimous decision, but the majority only cited Locke to support the notion that play in the joints existed. $^{204}$ Justice Thomas filed a concurring opinion in which he addressed and rejected what he called "the federalism aspect" of Ohio's argument; his rejection, however, was based on a narrow historical reading of the word "establishment," and did not specifically attack Ohio's contention that Locke fundamentally redefined the state-federal Religion Clause relationship. ${ }^{205}$ A similar argument has been raised in an amicus brief to the Court in the upcoming assisted suicide case, Gonzalez v. Oregon. ${ }^{206}$

In essence, by creating the zone of discretion in the religion clauses, the Locke court gave at least implied legitimacy to the notion that, within certain limits, the federal government is not authorized to interfere with

199. Brief for Respondents at *1, Cutter, 125 S. Ct. 2113 (No. 03-9877), available at 2005 WL 363713.

200. Id. at $* 1$.

201. Id.

202. Id. at *11.

203. Id. (internal citation omitted).

204. Cutter, 125 S. Ct. at 2117,2121

205. Id. at 2125-29 (Thomas, J., concurring).

206. Brief for 52 Religious and Religious Freedom Organizations and Leaders as Amici Curiae Supporting Respondents at*16-18, Gonzalez v. Oregon, 125 S. Ct. 1299 (2005) (No. 04-623), available at 2005 WL 1687166. The Respondents seek to invalidate a directive by then-Attorney General John Ashcroft that would strip any physician assisting in the death of another under Oregon's Death With Dignity Act of the ability to prescribe medication. The brief cites Locke in support of the proposition that states may draw a more stringent line than does the United States Constitution to better protect its citizenry. The brief further states that "[s]uch state prerogatives to grant enhanced religious freedoms also spring in part from the role of the states as "experimental laboratories' under the principles of federalism." Id. at * 17 . 
state religious policy. This argument has yet to be squarely addressed by any federal court. Given, however, that in the brief interval since Locke was decided, such an argument has been made in such disparate contexts as prisoner worship and euthanasia, Locke can be seen as another tool for use by states attempting to resist what they perceive as federal encroachment on their legislative prerogatives. Locke makes this possible by pushing Religion Clause jurisprudence down the path toward a greater accommodation of state and local preferences, but fails to flesh out the doctrine or set out any ground rules, making it quite likely that a good deal of litigation based on the intersection of federalist and Religion Clause concerns will be seen in the next few years.

\section{CONCLUSION}

The Supreme Court's ruling in Locke v. Davey seems to be motivated by prudent concerns, even if imperfectly justified. The decision is not likely to significantly increase the opportunities for religious discrimination. The decision has the added benefit of prescribing previously undefined limits on both the Lukumi and the Zelman decisions. The decision restores a certain amount of rightful, policy-making authority to state and local elected lawmakers, both in the area of religious education and beyond. Perhaps most importantly, it steps toward bringing free-exercise analysis in line with benefit-burden analysis in other areas of constitutional law, and it helps to clarify that, as between religion and secularism, the proper analysis is not one of equal protection.

The decision's primary weakness lies in its inability or unwillingness to clearly define the boundaries of state and local discretion as regards free exercise. Had the Court done so, the dissent's fears of an indefinite extension of the majority's logic would have proved unfounded. Further, Locke does little to stem the flow of litigation by citizens demanding that their states make funding available to them for private school tuition. A holding by the majority clarifying the free exercise boundaries of the zone of discretion - for example, allowing incidental implication of free exercise or a de minimis burden on free exercise-would have quelled fears of unmedicated clergymen. While it is not particularly difficult to divine such standards through prior precedent, the opinion would have been the stronger for an explicit recognition of these, or similar standards.

While maintaining a strict standard toward obviously hostile treatment of religion, the Court has reaffirmed a commitment, alluded to by at least one Justice in his Zelman concurrence, to allow states the 
flexibility to experiment with differing policies regarding religion and public funding. ${ }^{207}$ While not necessarily providing any more individual rights protection than before the decision, Locke seems to have delivered at least a modicum of clarity as to which direction the Court seems to be traveling in Religion Clause jurisprudence.

207. Zelman v. Simmons-Harris, 536 U.S. 639, 680 (2002) (Thomas, J., concurring) (arguing against the dissent's attempt "to handcuff the State's ability to experiment with education"). 